\title{
PODSTAWA EGZEKUCJI ADMINISTRACYJNEJ OBOWIĄZKÓW NIEPIENIĘŻNYCH W PRAWIE NIEMIECKIM I POLSKIM
}

\section{UWAGI WPROWADZAJĄCE}

Wdrożenie administracyjnego środka egzekucyjnego $\mathrm{w}$ prawie niemieckim i polskim może nastąpić, ze względu na konieczność ochrony zobowiązanego, tylko z uwzględnieniem restrykcyjnych przepisów o postępowaniu przymusowym $\mathrm{w}$ administracji ${ }^{1}$. W doktrynie prawa niemieckiego postępowanie to w odniesieniu do niepieniężnych obowiązków działania, znoszenia lub zaniechania w swym typowym kształcie określane jest jako regularne postępowanie przymusowe $^{2}-\mathrm{w}$ odróżnieniu od procedury tak zwanego natychmiastowego wykonania oraz egzekucyjnego postępowania uproszczonego. In genere zaś postępowanie egzekucyjne $\mathrm{w}$ administracji definiuje się $\mathrm{w}$ niemieckim orzecznictwie sądowym jako państwowe postępowanie przymusowe prowadzone przez organ administracji, w którym organ ten zmierza do realizacji roszczenia publicznoprawnego podmiotu władzy (np. gminy) w stosunku do obywatela przy zastosowaniu środków przymusu państwowego ${ }^{3}$.

Polska ustawa o postępowaniu egzekucyjnym w administracji nie zawiera definicji legalnej tego postępowania, lecz stanowi w art. 1 u.p.e.a. między innymi, że określa ona prowadzone przez organy egzekucyjne postępowanie i stosowane przez nie środki przymusu służące doprowadzeniu do wykonania przez zobowiązanych obowiązków wymienionych w art. 2 tego aktu. Naczelny Sąd Administracyjny wskazał zaś w wyroku z 26 marca 2009 r., że postępowanie egzekucyjne $\mathrm{w}$ administracji stanowi zorganizowany ciag czynności procesowych podejmowanych przez organy egzekucyjne oraz inne podmioty

${ }^{1}$ Por. H. Maurer, Allgemeines Verwaltungsrecht, München 2009, s. 515, nb. 20; zob. w prawie polskim: E. Bojanowski, Konstrukcja administracyjnych środków egzekucyjnych, w: J. Niczyporuk, S. Fundowicz, J. Radwanowicz, System egzekucji administracyjnej, Warszawa 2004, s. 145 oraz treść art. $7 \S 1$ ustawy z 17 czerwca 1966 r. o postępowaniu egzekucyjnym w administracji, tekst jedn.: Dz. U. 2005, Nr 229, poz. 1954 z późn. zm. (dalej jako: u.p.e.a.).

2 „Gestrecktes Zwangsverfahren”, dosłownie: „rozciagnięte postępowanie przymusowe”. Zob. H.-D. Lemke, Verwaltungsvollstreckung des Bundes und der Länder. Eine systematische Darstellung, Baden-Baden 1997, s. 121 i n.

${ }^{3}$ Bundesfinanzhof (Federalny Trybunał Finansowy), wyrok z 22 października 2002 r., VII R 56/00, „Entscheidungen des Bundesfinanzhofs” nr 199, poz. 511 (= „Neue Juristische Wochenschrift” [dalej jako: NJW] 2003, s. 1070); zob. też: H. Lisken, E. Denninger, Handbuch des Polizeirechts, München 1996, s. 676; K. Weber, Handbuch des sächsischen Verwaltungsvollstreckungsrechts, Dresden 2009, s. 20. 
w celu przymusowego wykonania obowiązków objętych egzekucją administracyjna ${ }^{4}$. W ocenie zaś niektórych przedstawicieli polskiej nauki prawa postępowaniem egzekucyjnym $\mathrm{w}$ administracji w szerokim znaczeniu można nazwać wszystkie postępowania wszczynane i prowadzone w związku z niewykonaniem obowiązku o charakterze administracyjnoprawnym. Autorzy ci zauważaja, że wskazane postępowania występują niekiedy w nauce pod tradycyjną nazwą: postępowania przymusowe ${ }^{5}$.

Jeden z czołowych przedstawicieli niemieckiej nauki o przymusie administracyjnym - Hanno-Dirk Lemke - wskazuje, że w typowym przypadku ustawa o egzekucji administracyjnej ${ }^{6}$ wymaga istnienia podstawy egzekucji, która tworzy zasadniczo akt administracyjny, ,zarządzenie podstawowe” (die Grundverfügung), ewentualnie - gdy przepisy prawa o egzekucji administracyjnej tak stanowią - umowa publicznoprawna albo tytuł sądowoadministracyjny. Dalszym wymogiem egzekucji jest wykonalność aktu administracyjnego, która zachodzi wówczas, gdy akt ten jest niezasakrżalny albo środek zaskarżenia przeciwko niemu nie wywołuje skutku zawieszającego. Tylko wyjątkowo możliwe jest w regularnym postępowaniu egzekucyjnym zastosowanie środków egzekucyjnych przed uzyskaniem przez akt administracyjny przymiotu wykonalności ${ }^{7}$.

\section{INDYWIDUALNY AKT ADMINISTRACYJNY}

\section{Ustawowe określenie terminu}

Jedną z przesłanek egzekucji świadczeń niepieniężnych w regularnym postępowaniu przymusowym $\mathrm{w}$ administracji jest istnienie indywidualnego tak zwanego podstawowego aktu administracyjnego (,zarządzenia podstawowego"8), który stanowi o obowiązku działania, znoszenia lub zaniechania (§ 6 ust. 1 VwVG; art. $2 \S 1$ pkt 3 i art. $3 \S 1$ u.p.e.a.). W doktrynie niemieckiej indywidualny akt administracyjny wydany względem zainteresowanego określa się niekiedy mianem tytułu egzekucyjnego ${ }^{9}$. Polskie rozporządzenie

${ }^{4}$ II FSK 1462/08, Centralna Baza Orzeczeń Sądów Administracyjnych, http://www.orzeczenia. nsa.gov.pl (dalej jako: CBOSA). Por. też: Z. Leoński, w: R. Hauser, Z. Leoński, Egzekucja administracyjna. Komentarz do ustawy z 17 czerwca 1966 r. o postępowaniu egzekucyjnym $w$ administracji, Warszawa 1983, s. 5.

${ }^{5}$ P. Przybysz, Podstawowe dylematy nauki o postępowaniu egzekucyjnym w administracji, w: J. Boć, A. Chajbowicz, Nowe problemy badawcze $w$ teorii prawa administracyjnego, Wrocław 2009, s. 871-872; J. Jendrośka, Polskie postępowanie administracyjne, Wrocław 2001, s. 15; A. Skoczylas, Postepowanie egzekucyjne $w$ administracji, w: R. Hauser, Z. Niewiadomski, A. Wróbel (red.), System prawa administracyjnego, t. 9: Prawo procesowe administracyjne, Warszawa 2010, s. 320-321; tak szeroko postępowanie egzekucyjne ujmuje się też często w orzecznictwie sądowoadministracyjnym, np. wyrok NSA z 7 stycznia 2010 r., II FSK 1289/08, CBOSA.

${ }^{6}$ Verwaltungsvollstreckungsgesetz vom 27. April 1953, BGBl. I, s. 157 ze zm. (dalej jako: VwVG).

7 H.-D. Lemke, op. cit., s. 121 i n.

8 ,Grundverfügung”.

9 ",Vollstreckungstitel”; zob. Ch. Gusy, Polizeirecht, Tübingen 2000, s. 246, nb. 350; O. Seewald, Polizei und Sicherheitsrecht. Ein Gemeinschafts-Skript, Passau 1995, maszynopis, s. 244. Ostatni $\mathrm{z}$ wymienionych autorów stwierdza, że w przeciwieństwie do wierzyciela prywatnoprawnego, organ 
Prezydenta Rzeczypospolitej z 20 marca 1928 r. o postępowaniu przymusowym w administracji ${ }^{10}$ (Dz. U. RP Nr 36, poz. 342 z późn. zm.) stanowiło w art. 14 ust. 1 pkt c) o tytule wykonawczym będącym podstawą wdrożenia postępowania przymusowego, który mogły stanowić - dotyczące poszczególnych osób orzeczenia, zarządzenia, nakazy lub zakazy przewidziane przez prawo. Obecnie zaś terminem ,tytuł egzekucyjny” w stosunku do decyzji nakładającej na stronę obowiązek podlegający wykonaniu w trybie przepisów o postępowaniu egzekucyjnym $\mathrm{w}$ administracji posługuje się na gruncie prawa polskiego między innymi Barbara Adamiak ${ }^{11}$.

W obowiązującej niemieckiej ustawie federalnej o postępowaniu administracyjnym w $§ 35$ zd. I ${ }^{12}$ zdefiniowano akt administracyjny jako każde zarządzenie, rozstrzygnięcie albo inne działanie władcze, które organ podejmuje dla uregulowania konkretnego przypadku w obszarze prawa publicznego i które zmierza do wywołania bezpośredniego skutku prawnego na zewnątrz ${ }^{13}$. Należy zauważyć, że ta definicja legalna odpowiada zasadniczo konstrukcji aktu administracyjnego - decyzji - wydawanej w polskim postępowaniu administracyjnym (art. $104 \mathrm{w}$ zw. z art. 1 pkt 1 ustawy z 14 czerwca 1960 r. - Kodeks postępowania administracyjnego ${ }^{14}$ ).

Polski Kodeks postępowania administracyjnego nie formułuje wprawdzie legalnej definicji decyzji jako indywidualnego aktu administracyjnego (decyzji, postanowienia), jednak $\mathrm{w}$ poszczególnych jego przepisach (art. 1 pkt 1, art. 3 $\S 3$ i art. 1 pkt 2 k.p.a. w zw. z art. 7 Konstytucji RP oraz art. 6 i art. 107 $\S 1$ k.p.a.) zawarte zostały pewne elementy i cechy, które przy uwzględnieniu ustaleń teorii prawa i postępowania administracyjnego oraz bogatego orzecznictwa NSA pozwalają na jej rekonstrukcję ${ }^{15}$. Podnosi się ponadto, że gdy

administracji publicznej sam tworzy tytuł egzekucyjny przez wydanie aktu administracyjnego (,zarządzenia podstawowego”). Zob. B. Adamiak, w: eadem, J. Borkowski, R. Mastalski, J. Zubrzycki, Ordynacja podatkowa. Komentarz, Wrocław 2009, s. 917.

${ }^{10}$ Dz. U. RP Nr 36, poz. 342 ze zm.

${ }^{11}$ Zob. B. Adamiak, w: eadem, J. Borkowski, R. Mastalski, J. Zubrzycki, op. cit., s. 917.

${ }_{12}$ Verwaltungsverfahrensgesetz vom 25. Mai 1976 in der Fassung der Bekanntmachung vom 23. Januar 2003, BGBl. I, s. 102 ze zm. (dalej jako: VwVfG).

${ }^{13} \mathrm{~W}$ orzecznictwie NSA i polskiej doktrynie prawa za decyzję administracyjną uznaje się jednostronne rozstrzygnięcie organu administracji o wiążących konsekwencjach obowiązującej normy prawa administracyjnego dla indywidualnie określonego podmiotu i konkretnej sprawy, podejmowane w sferze stosunków zewnętrznych, poza systemem organów państwowych i podległych im jednostek - por. uchwała składu siedmiu sędziów NSA z 12 października 1998 r., OPS 6/98, ONSA 1999, nr 1, poz. 3; wyrok NSA z 15 grudnia 1987 r., SA/Wr 730/87, ONSA 1988, nr 1, poz. 18; wyrok NSA z 5 października 1982 r., II SA 969/82, OSPiKA 1985, nr 9, poz. 163; uchwała SN z 5 lutego 1988 r., III AZP 1/88, OSPiKA 1989, nr 3, poz. 59; J. Zimmermann, Motywy decyzji administracyjnej i jej uzasadnienie, Warszawa 1981, s. 4 i n.; idem, Polska jurysdykcja administracyjna, Warszawa 1996, s. 133-140; J. Swiątkiewicz, Decyzja administracyjna w świetle orzecznictwa Naczelnego Sadu Administracyjnego, „Nowe Prawo” 1985, nr 9, s. 31; T. Woś, w: idem (red.), H. Knysiak-Molczyk, M. Romańska, Prawo o postępowaniu przed sadami administracyjnymi. Komentarz, Warszawa 2011, s. 50; J. Borkowski, Zmiana i uchylanie ostatecznych decyzji administracyjnych, Warszawa 1967, s. 11 i n.; idem, w: R. Hauser, Z. Niewiadomski, A. Wróbel (red.), op. cit., t. 9, s. 151 i n.; K. Ziemski, Decyzja deklaratoryjna a konstytutywna - teoria i praktyka, w: Z. Czarnik, J. Niewiadomski, J. Posłuszny, J. Stelmasiak, Studia z prawa administracyjnego i nauki o administracji. Księga jubileuszowa dedykowana Prof. zw. dr. hab. Janowi Szreniawskiemu, Przemyśl-Rzeszów 2011, s. 986 i n.

${ }^{14}$ Dz. U. Nr 30, poz. 168 ze zm.

${ }_{15}$ T. Woś, w: idem (red.), H. Knysiak-Molczyk, M. Romańska, Prawo o postępowaniu przed sadami administracyjnymi. Komentarz, Warszawa 2011, s. 50. 
uprawnienia strony nie powstają bezpośrednio z mocy prawa, lecz w wyniku konkretyzacji normy prawnej, organ administracji - jeśli nie jest przewidziana inna forma jego działania - obowiązany jest dokonać tej konkretyzacji w drodze decyzji administracyjnej ${ }^{16}$. Jednocześnie podkreśla się, że ze względu na zawarta $\mathrm{w}$ art. 104 k.p.a. zasadę załatwiania indywidualnych spraw administracyjnych przez wydanie decyzji wyłączenie decyzyjnej formy załatwiania takich spraw musi być wyraźne; nie można go domniemywać ${ }^{17}$.

Należy wskazać, że w zdaniu II § 35 VwVfG wyróżniono ponadto tak zwane zarządzenia ogólne ${ }^{18}$, które definiowane są jako akty administracyjne skierowane do określonej według ogólnych cech lub dającej się określić grupy osób albo dotyczące publicznoprawnej właściwości rzeczy lub jej użytku przez ogół. Kategorię taką wyodrębniało również wspomniane wyżej, polskie rozporządzenie z 20 marca 1928 r., które wśród tytułów wykonawczych wymieniało także tak zwane zarządzenia ogólne władzy, przewidziane przez prawo, a skierowane bądź do ogółu, bądź do określonej grupy osób (art. 14 pkt 1 lit. b).

Często ustawy z zakresu zarówno polskiego, jak i niemieckiego materialnego prawa administracyjnego nie używają określenia ,akt administracyjny”, lecz posługują się innym nazewnictwem ${ }^{19}$, na przykład „nakaz” usunięcia budowli w prawie budowlanym, ,zarządzenie” zamknięcia w prawie gospodarczym, czy znoszenia wstępu na grunt (np. według $\$ 17$ ust. 2 ustawy federalnej z 17 września 1953 r. o rzemiośle ${ }^{20}$ ), ,wstrzymanie” ruchu drogowego, ,,przejęcie w użytkowanie" nieruchomości i ruchomości, przedmiotów i urządzeń przydatnych $\mathrm{w}$ działaniu ratowniczym (według art. 16 polskiej ustawy z 6 kwietnia 1990 r. o Policji ${ }^{21}{ }^{22}$. Z kolei klasycznym przykładem wspomnianych zarządzeń ogólnych są znaki nakazu i zakazu - w rozumieniu § 41 ust. 1 niemieckiego rozporządzenia z moca ustawy z 28 maja $1934 \mathrm{r}$. - Prawo o ruchu drogowym $^{23}$.

\section{Obowiazki podlegajace przymusowemu wykonaniu}

Treścią powyższych aktów są publicznoprawne obowiązki działania, znoszenia lub zaniechania. W rozumieniu ustaw egzekucyjnych Niemiec i Polski, egzekucji administracyjnej podlegaja zatem tylko obowiązki o charakterze publicznoprawnym ${ }^{24}$, czyli takie, które wynikaja z władczych rozstrzygnięć organów administracji rządowej i samorządowej lub bezpośrednio

\footnotetext{
${ }^{16}$ Wyrok NSA z 31 sierpnia 1984 r., SA/Wr 430/84, OSPiKA 1986, z. 9-10, poz. 176; postanowienie NSA z 29 listopada 2011 r., II GSK 1677/11, CBOSA.

${ }_{17}$ Wyrok NSA z 23 stycznia 1998 r., II SA 1329/97, ONSA 1998, nr 4, poz. 137.

18 „Allgemeinverfügungen”.

19 W. Dawidowicz, $Z$ problematyki zatatwiania spraw $w$ formie decyzji organu administracji państwowej w świetle orzecznictwa NSA, Gdańsk 1983, s. 6-7.

${ }^{20}$ Gesetz zur Ordnung des Handwerks vom 17. September 1953, BGBl. 1998, I, s. 3074.

${ }^{21}$ Tekst jedn.: Dz. U. 2007, Nr 43, poz. 277 ze zm.

${ }^{22}$ Zob. Z. Leoński, R. Hauser, w: R. Hauser, A. Skoczylas (red.), Postepowanie egzekucyjne w administracji. Komentarz, Warszawa 2011, s. 19.

${ }^{23}$ Strassenverkehrs-Ordnung vom 28. Mai 1934, in der Fassung der Bekanntmachung vom 16. November 1970, BGBl. I, s. 1565 ze zm.

${ }^{24}$ Zob. wyrok NSA z 23 maja 1994, IV SA 791/93, „Glosa” 1996, nr 12, s. 33, LexPolonica, nr 313878.
} 
z przepisów prawa ${ }^{25}$. Wykluczone są tu zatem obowiązki cywilnoprawne, chyba że przepis szczególny przekazuje do egzekucji administracyjnej tego typu obowiązki $^{26}$. Polska ustawa egzekucyjna posługuje się pojęciem obowiązków o charakterze niepieniężnym (art. $2 \S 1$ pkt 10 u.p.e.a.), nie precyzując jednak charakteru tych obowiązków, wskazuje jedynie pewne ich rodzaje w przepisach normujących środki egzekucyjne tego rodzaju obowiązków ${ }^{27}$.

Ustawa niemiecka (VwVG) owe obowiązki określa według rodzajów zachowań, do których podstawa egzekucji zobowiązuje jego adresata, czyli jako obowiązki działania, znoszenia lub zaniechania - dając temu wyraz w tytule rozdziału drugiego federalnej ustawy o egzekucji administracyjnej ${ }^{28}$. Pierwszy z wymienionych rodzajów obowiązków polega na zobowiązaniu adresata do aktywnego podjęcia jakichś czynności, na przykład do: wzięcia udziału w szkoleniach z zakresu ruchu drogowego, realizacji obowiązku szkolnego ${ }^{29}$, oddania prawa jazdy, zwrotu unieważnionego paszportu ${ }^{30}$, przekazania określonej dokumentacji ${ }^{31}$, doprowadzenia pojazdu mechanicznego do przeglądu, zastępczego zasadzenia drzewa, rozbiórki obiektu budowlanego albo niedopuszczalnych zmian w obiekcie zabytkowym, usunięcia odpadów ${ }^{32}$. Z kolei obowiązek znoszenia polega na zezwoleniu osobie uprawnionej do podjęcia określonych działań ${ }^{33}$, na przykład na udostępnieniu przez przedsiębiorcę swoich pomieszczeń gospodarczych i zezwoleniu przez niego na pobranie próbek do celów kontroli czy na przejściowym zakwaterowaniu przez posiadacza hotelu osób bezdomnych oraz azylantów ${ }^{34}$. Natomiast przymusowa realizacja obowiązku zaniechania powinna przejawiać się w tym, że zobowiązany nie występuje przeciwko zakazowi, na przykład przeciwko zakazowi prowadzenia działalności gospodarczej czy zakazowi zgromadzeń ${ }^{35}$. W $\$ 6$ ust. 1 VwVG i niektórych ustawach egzekucyjnych krajów związkowych wyodrębnia się ponadto jako posiadające ,,zdolność egzekucyjną” akty określające obowiązek

${ }^{25}$ Zob. Z. Leoński, Glosa do wyroku NSA z 23 maja 1994, IV SA 791/93, OSP 1996, nr 7-8, s. 333.

${ }^{26}$ W literaturze polskiej podaje się jako przykład art. 34 ustawy z 21 czerwca 2001 r. o ochronie praw lokatorów, mieszkaniowym zasobie gminy i o zmianie Kodeksu cywilnego (tekst jedn.: Dz. U. 2005, Nr 31, poz. 266 z późn. zm.), który przewiduje, że orzeczenia sądowe, a także decyzje administracyjne wydane i niewykonane przed dniem wejścia w życie powyższej ustawy są wykonywane w trybie egzekucji administracyjnej prowadzonej przez organy gminy; por. Z. Leoński, R. Hauser, w: R. Hauser, A. Skoczylas (red.), op. cit., s. 19.

${ }^{27}$ Zob. R. Hauser, A. Skoczylas, w: K. Celińska-Grzegorczyk, R. Hauser, W. Sawczyn, A. Skoczylas, Postepowanie administracyjne, sqdowoadministracyjne i egzekucyjne, Warszawa 2009, s. 192.

28 „Erzwingung von Handlungen, Duldungen oder Unterlassungen” - dosł.: „Wymuszenie działań, znoszeń lub zaniechań”.

${ }^{29}$ W myśl art. 20 ustawy z 7 września 1991 r. o systemie oświaty, tekst jedn.: Dz. U. 2004, Nr 256, poz. $2572 \mathrm{ze} \mathrm{zm}$.

${ }^{30}$ Według art. 39 ust. 5 ustawy z 13 lipca 2006 r. o dokumentach paszportowych, Dz. U. Nr 143, poz. $1027 \mathrm{ze} \mathrm{zm.}$

${ }^{31}$ Przykładowo: przekazania dokumentacji dotyczącej dziecka - w myśl art. 72 w zw. z art. 47 ust. 1 pkt 2 i ust. 2 ustawy z 9 czerwca 2011 r. o wspieraniu rodziny i systemie pieczy zastępczej, Dz. U. Nr 149 , poz. 887.

${ }^{32}$ R. Brühl, Die Prüfung der Rechtmäßigkeit des Verwaltungszwangs im gestreckten Verfahren, „Juristische Schulung” 1997, z. 11, s. 1023.

${ }^{33}$ H.-D. Lemke, op. cit., s. 71.

${ }^{34}$ R. Brühl, op. cit., s. 1023.

35 Ibidem oraz H.-D. Lemke, op. cit., s. 71-72. 
wydania rzeczy. Przy czym chodzi w tym wypadku jedynie o szczególny przypadek obowiązku działania, o którym z tego powodu większość ustawodawstw krajów związkowych nie wspomina.

Wymienione przykłady obowiązków niepieniężnych znamionuje to, że wyrażają one nakazy albo zakazy względem adresatów aktów, podlegające ustawie o egzekucji administracyjnej (tzw. przymusowi administracyjnemu Verwaltungszwang), $\mathrm{z}$ wyłączeniem obowiązku świadczenia pieniężnego, którego przymusowe wykonanie - jak wskazano - przebiega według odrębnych przepisów o egzekucji administracyjnej, to jest przepisów ustaw: Prawa daninowego ${ }^{36}$ (§ $249 \mathrm{i} \mathrm{n}$.), § 66 księgi 10 Kodeksu socjalnego ${ }^{37}$ oraz rozporzadzenia z 11 marca 1937 r. o ściaganiu kosztów wymiaru sprawiedliwości ${ }^{38}$. Akty administracyjne obejmujace obowiązki nakazu lub zakazu nazywane sa z tego względu aktami nakazującymi ${ }^{39}$. Omawianemu trybowi egzekucji administracyjnej nie podlegaja natomiast - jako nieposiadające „zdolności egzekucyjnej”, a co więcej - jako niepotrzebujące egzekucji - akty administracyjne, które jedynie stwierdzają istotne prawnie właściwości, istnienie lub nieistnienie stosunku prawnego albo określone prawa lub obowiązki ${ }^{40}$. Także akty prawo kształtujące - to znaczy akty administracyjne, które ustanawiaja, zmieniaja albo znoszą prawo lub stosunek prawny - nie są wykonalne, jeśli nie obejmuja swą treścią dodatkowo nakazu albo zakazu. Przez to bowiem, że akt administracyjny prawo kształtujący kreuje nowy stan prawny, niejako niesie on sam w sobie wykonanie. Zaliczaja się do tego rodzaju aktów przede wszystkim udzielenie i uchylenie pozwolen ${ }^{41}$.

\section{WYJĄTKI OD ZASADY ISTNIENIA INDYWIDUALNEGO AKTU ADMINISTRACYJNEGO}

Przymus administracyjny ${ }^{42}$ jest dopuszczalny wyjątkowo także bez istnienia indywidualnego aktu administracyjnego, mianowicie - w prawie niemieckim wtedy gdy ze względu na niebezpieczeństwo w zwłoce konieczne jest natychmiastowe działanie. $\mathrm{W}$ prawie polskim ustawodawca dopuszcza natomiast egzekucję administracyjną obowiązków wynikających bezpośrednio z przepisów prawa - jeżeli należy to do właściwości organów administracji rządowej albo jednostek samorządu terytorialnego (art. 3 § 1 u.p.e.a.). Chodzi tu o instytucję natychmiastowego wykonania ${ }^{43}$ (§ 6 ust. 2 VwVG; art. 150

\footnotetext{
${ }^{36}$ Abgabenordnung (AO) vom 1. Oktober 2002, BGBl. I, s. 3869.

37 Zehntes Buch des Sozialgesetzbuches vom 18. August 1980, BGBl. 2001, I, s. 130.

38 Justizbeitreibungsordnung vom 11. März 1937, BGBl. I, s. 298.

39 „Befehlende Verwaltungsakte”; zob. H. Maurer, op. cit., s. 507, nb. 6.

${ }^{40}$ Akty administracyjne stwierdzające - „feststellende Verwaltungsakte”; zob. H. Maurer, op. cit., s. 217-218 i 507; H.-D. Lemke, op. cit., s. 73.

${ }^{41}$ H.-D. Lemke, op. cit., s. 74; por. też: H. Maurer, op. cit., s. 507, nb. 6.

${ }^{42} \mathrm{~W}$ znaczeniu podanym wyżej, tzn. jako egzekucja administracyjna w zakresie obowiązków działania, znoszenia lub zaniechania.

${ }^{43}$ W doktrynie prawa odróżnia się „,natychmiastowe wykonanie” (sofortiger Vollzug) - w znaczeniu przedstawionym w niniejszym rozdziale, od ,wykonania bezpośredniego” (unmittelbare Ausführung).
} 
§ 3 u.p.e.a.). Gerhárd Sadler określa ja jako samodzielny, materialny przejaw oraz sposób zastosowania przymusu administracyjnego w przypadkach nagłych obrony przed niebezpieczeństwem, bez uprzedniego wydania aktu administracyjnego ${ }^{44}$. Możliwość zastosowania przymusu administracyjnego bez wydania aktu administracyjnego jako podstawy egzekucji, w celu udaremnienia czynu niezgodnego z prawem - wypełniającego znamiona czynu zabronionego albo gdy jest to konieczne dla zapobieżenia grożącemu niebezpieczeństwu i jednocześnie organ działa w ramach swych ustawowych kompetencji - przewiduje wskazany przepis $\S 6$ ust. 2 VwVG.

Natomiast w polskim systemie egzekucji administracyjnej organy egzekucyjne wykonujace przymusowo obowiązki publicznoprawne, które wynikaja wprost z przepisów prawa, czyli z aktów o charakterze generalnym, bez potrzeby wydawania aktu indywidualnego, moga stosować niezwłocznie przymus bezpośredni - to znaczy bez uprzedniego upomnienia zobowiązanego i doręczania mu odpisu tytułu wykonawczego i postanowienia nakładającego ten środek egzekucyjny, a jedynie po ustnym wezwaniu zobowiązanego do wykonania obowiązku - jeżeli zwłoka w wykonaniu może zagrozić życiu lub zdrowiu albo spowodować niemożność lub znaczne utrudnienie w dochodzeniu wykonania przez zobowiązanego obowiązku, a także w innych przypadkach określonych $\mathrm{w}$ odrębnych przepisach (art. 150 § 3 u.p.e.a.) ${ }^{45}$. Jako przykład obowiązku wynikającego wprost $\mathrm{z}$ przepisu prawa podaje się obowiązek zaszczepienia psa przeciwko wściekliźnie, ciążący na posiadaczu tego zwierzęcia ${ }^{46}$. Innym przykładem były do 17 sierpnia 2005 r. ${ }^{47}$ - wynikające $\mathrm{z}$ art. 5 ust. 1 ustawy z 13 września $1996 \mathrm{r}$. o utrzymaniu porządku i czystości $\mathrm{w}$ gminach ${ }^{48}$ - obowiązki właścicieli nieruchomości dotyczące zapewnienia utrzymania czystości i porządku w granicach tych nieruchomości i chodników położonych wzdłuż nieruchomości ${ }^{49}$. Po tym dniu w przypadku stwierdzenia przez wójta (burmistrza, prezydenta miasta) niewykonania tych obowiązków,

Oba pojęcia rozróżnia się przez to, że natychmiastowe wykonanie może zostać wdrożone przeciwko domniemanej woli zobowiązanego, podczas gdy wykonanie bezpośrednie jako instytucja prawa policyjnego jest dopuszczalne także wtedy, gdy zainteresowany zgadza się z treścią obowiązku, np. właściciel nieruchomości z usunięciem gleby nasyconej ropą naftową poprzez natychmiastowe zlecenie przez policję odpowiednich czynności przedsiębiorcy - zob. H. Maurer, op. cit., s. 516-517; M. App, A. Wettlaufer, Verwaltungsvollstreckungsrecht, Köln-Berlin-Bonn-München 1987, s. 191-192, nb. 24-26. W doktrynie polskiej mowa jest o ,przymusie natychmiastowym” - zob. W. Sawczyn, w: R. Hauser, A. Skoczylas (red.), op. cit., s. 612; A. Skoczylas, w: R. Hauser, Z. Niewiadomski, A. Wróbel (red.), op. cit., t. 9 , s. 454 .

${ }^{44}$ G. Sadler, Sofortige Vollziehung und sofortiger Vollzug in der Praxis, „Polizei” 2005, s. 187.

45 Por. R. Hauser, A. Skoczylas, w: K. Celińska-Grzegorczyk, R. Hauser, W. Sawczyn, A. Skoczylas, op. cit., s. 216; P. Pietrasz, w: J. Dembczyńska, P. Pietrasz, K. Sobieralski, R. Suwaj, Praktyka postepowania egzekucyjnego $w$ administracji, Wrocław 2008, s. 111 oraz powołany tam wyrok WSA w Warszawie z 23 marca 2006, III SA/Wa 29/06, Lex, nr 197549.

${ }^{46}$ Obowiązek ten wynika z art. 56 ust. 2 ustawy z 11 marca 2004 r. o ochronie zdrowia zwierząt oraz zwalczaniu chorób zakaźnych zwierząt, Dz. U. Nr 69, poz. 625 ze zm.

${ }^{47}$ Czyli do dnia wejścia w życie ustawy nowelizującej ustawę o zbiorowym zaopatrzeniu w wodę i zbiorowym odprowadzeniu ścieków, Dz. U. 2005, Nr 85, poz. 729.

${ }^{48}$ Tekst jedn.: Dz. U. 2005, Nr 236, poz. 2008 ze zm. (dalej jako: u.p.c.g.).

49 Zob. np. wyrok WSA w Gliwicach z 10 sierpnia 2006, II SA/Gl 887/05, CBOSA, odnoszący się do obowiązku właściciela nieruchomości w zakresie przyłączenia jej do istniejącej sieci kanalizacyjnej. 
wydaje on decyzję nakazująca ich wykonanie, która następnie może stać się podstawa egzekucji administracyjnej ${ }^{50}$. Wyjątkiem od tej nowej reguły sa obowiązki dotyczące zbierania i pozbywania się zebranych na terenie nieruchomości odpadów komunalnych oraz nieczystości ciekłych, które w związku z tym moga podlegać przymusowemu wykonaniu bez konieczności istnienia decyzji administracyjnej. $Z$ kolei przykładem obowiązku zaniechania wypływającym wprost $\mathrm{z}$ ustawy jest zakaz wypasu zwierząt gospodarczych $\mathrm{w}$ pasie drogowym ${ }^{51}$. Czy dla wymuszenia wykonania wspomnianych obowiązków właściwe będzie zastosowanie grzywny w celu przymuszenia, czy przymus bezpośredni, będzie kwestią oceny organu egzekucyjnego ${ }^{52}$. W szczególnych zaś okolicznościach obowiązek takiego typu może zostać przymusowo wykonany $\mathrm{w}$ trybie natychmiastowego zastosowania przymusu bezpośredniego. Wypada dodać, że w doktrynie prawa i orzecznictwie podkreśla się, iż jeśli obowiązek ciąży na podmiocie z mocy samego prawa, wydana w rezultacie przeprowadzonego postępowania decyzja nakładająca na podmiot obowiązek wynikający $\mathrm{z}$ przepisu prawa jest bezprzedmiotowa $\mathrm{w}$ rozumieniu art. $105 \S 1$ k.p.a. ${ }^{53}$

Po drugie zaś, organy właściwe dla ochrony spokoju, bezpieczeństwa i porządku publicznego, zdrowia lub mienia moga - w sytuacjach niebezpieczeństwa dla życia lub zdrowia ludzkiego albo ciężkich szkód dla gospodarstwa narodowego lub jeśli wymaga tego szczególny interes społeczny stosować w celu wyegzekwowania wydanych bezpośrednio ustnych poleceń środki egzekucyjne $\mathrm{w}$ postaci wykonania zastępczego, odebrania rzeczy ruchomej albo przymusu bezpośredniego, bez potrzeby wystawienia tytułu wykonawczego i doręczenia zobowiązanemu postanowienia o zastosowaniu danego środka przymusu (art. 117 u.p.e.a. ${ }^{54}$.

W doktrynie prawa niemieckiego zauważa się, że instytucja natychmiastowego wykonania stanowi najostrzejszy środek przymusu administracyjnego ${ }^{55}$. Dlatego w myśl art. 20 ust. 3 GG uprawnienie organu do natychmiastowego wykonania może być stosowane wyłącznie w granicach wyraźnie określonych $\mathrm{w}$ wyżej wspomnianych przepisach do tego upoważniajacych ${ }^{56}$. Przy tym podkreśla się, że cel natychmiastowego wykonania wynika z $\S 6$ ust. 1 VwVG, w którym chodzi o przymusową realizację obowiązków publicznoprawnych

50 Art. 5 ust. 7 i 9 u.p.c.g.

${ }^{51}$ Zob. art. 39 ust. 1 pkt 10 ustawy z 21 marca 1985 r. o drogach publicznych, tekst jedn.: Dz. U. 2007, $\mathrm{Nr} 19$, poz. 115 ze zm.

52 Por. Z. Leoński, W. Sawczyn, w: R. Hauser, A. Skoczylas (red.), op. cit., s. 610, nb. 10.

${ }^{53}$ Por. P. Pietrasz, w: J. Dembczyńska, P. Pietrasz, K. Sobieralski, R. Suwaj, op. cit., s. 111; por. też wyrok NSA z 30 grudnia 1998, IV SAB 64/98, Lex, nr 45132.

${ }^{54} \mathrm{~W}$ tym wypadku, posługując się terminologią przyjętą w doktrynie niemieckiej, można byłoby mówić o „wykonaniu bezpośrednim”, które jest niezależne od istnienia źródła obowiązku, a charakteryzuje się egzekwowaniem wydanych bezpośrednio ustnych poleceń, zwłaszcza przez organy odpowiedzialne za zapewnienie bezpieczeństwa i porządku publicznego (Policji, straży gminnych, innych służb), a także ochrony zdrowia i mienia (np. Straży Pożarnej). Na temat szerokiej gamy możliwych sytuacji tego typu - zob. R. Szałowski, Prawnoadministracyjne kompetencje Policji, Łódź 2010, passim.

${ }_{55}$ G. Sadler, op. cit., s. 187.

${ }^{56}$ Federalny Sąd Administracyjny stwierdził, że $§ 6$ ust. 2 stanowi samodzielną i w pełni wystarczająca podstawę prawną omawianej ingerencji w sytuacjach nagłych, zob. Bundesverwaltungsgericht, wyrok z 11 listopada 1993 r., 3 C 45/91, NJW 1994, s. 3020. 
omawianego rodzaju. O ile jednak w regularnym postępowaniu przymusowym chodzi o skłonienie zobowiązanego do wykonania przezeń obowiązków, o tyle przy natychmiastowym wykonaniu dochodzi do czystego zastosowania przymusu administracyjnego ${ }^{57}$. Wynika to ze specyfiki tego rodzaju przypadków, w których zainteresowany jest często nieobecny i stąd nie ma obiektywnej możliwości wpłynięcia na jego zachowanie. Ponadto na gruncie prawa niemieckiego w omawianej sytuacji wchodzi w gre jedynie zastosowanie wykonania zastępczego albo przymusu bezpośredniego ${ }^{58}$. Organ decyduje co do zasady $\mathrm{w}$ granicach uznania, czy zrealizuje przymus administracyjny we wskazanym trybie. Jednak ustawa może przewidywać wyjątki, w których owo uznanie zostaje ograniczone, a organ zobowiązany do przeprowadzenia postępowania egzekucyjnego ${ }^{59}$. Z reguły sytuacje takie maja miejsce $\mathrm{w}$ ramach czynności wykonawczych Policji i organów porządkowych, na przykład w przypadku odholowania pojazdu w ruchu ulicznym ${ }^{60}$.

Zastosowanie przymusu egzekucyjnego w ramach natychmiastowego wykonania, jak wspomniano już powyżej, nie następuje według rygorów formalnych regularnego postępowania egzekucyjnego $\mathrm{w}$ administracji. Jak stwierdza się w doktrynie prawa, natychmiastowe wykonanie odróżnia się od regularnego postępowania nie z punktu widzenia materialnych przesłanek egzekucji, lecz jedynie w zakresie realizacji przymusu ${ }^{61}$. Otóż, wspomniana instytucja może zostać zastosowana w razie konieczności natychmiastowego odparcia zagrożenia: po pierwsze - jak wskazano - bez tytułu egzekucyjnego, przy czym musza istnieć wszystkie prawne przesłanki wydania aktu administracyjnego ${ }^{62}$, po drugie zaś - bez wydania i obwieszczenia zobowiązanemu zagrożenia indywidualnego bądź ustanowienia środka przymusu. Warunkiem jest jednak działanie organu egzekucyjnego w ramach jego ustawowych kompetencji.

\section{ODPOWIEDNIE ZASTOSOWANIE PRZEPISÓW PRAWA O EGZEKUCJI ADMINISTRACYJNEJ}

\section{Tytuły sadowoadministracyjne}

Specyfika roli niemieckich i polskich sądów administracyjnych, a w związku z tym charakter orzeczeń tych sądów powodują, że uchylając zaskarżony akt, sąd nie ustala zasadniczo uprawnień i obowiązków na stałe i stwierdza jedynie,

${ }^{57}$ G. Sadler, op. cit., s. 187.

58 Ibidem.

${ }^{59}$ Por. Bundesverwaltungsgericht, wyrok z 18 sierpnia 1960 r., 1 C 42/59, NJW 1961, s. 793.

${ }^{60}$ G. Sadler, op. cit., s. 188; autor wskazuje przykładowo, że w Berlinie dziennie ma miejsce trzysta takich przypadków.

61 Ch. Gusy, op. cit., s. 258.

62 Stąd mówi się o ,hipotetycznym zarządzeniu podstawowym” (,hypothetische Grunverfügung”). 
że dotychczasowy układ nie był prawidłowy ${ }^{63}$. Polskie sądy administracyjne tylko na zasadzie wyjątku otrzymuja uprawnienia merytoryczne, natomiast $\mathrm{w}$ egzekucji $\mathrm{z}$ niemieckich wyroków sądowoadministracyjnych znajduja odpowiednie zastosowanie na podstawie § 168 ust. 1 VwGO - w ściśle określonych przypadkach - przepisy prawa o egzekucji administracyjnej. Dotyczyć to będzie tych przypadków, w których sąd administracyjny orzeka o obowiązkach jednostki ${ }^{64}$. W prawie polskim zaś możliwość odpowiedniego stosowania przepisów o egzekucji administracyjnej w ogóle nie wchodzi w grę. Wynika to przede wszystkim z różnic $\mathrm{w}$ kształcie prawnym orzeczeń sądów administracyjnych Niemiec i Polski. Nie oznacza to jednak nieistnienia w prawie polskim instrumentów umożliwiających przymuszenie organu administracji publicznej do wykonania wyroków sądowoadministracyjnych ${ }^{65}$.

\section{Umowy publicznoprawne oraz ugody}

Na gruncie prawa niemieckiego podstawę egzekucji administracyjnej moga tworzyć również umowy publicznoprawne w rozumieniu §54 ust. 1 VwVfG i odpowiednich przepisów krajów związkowych ${ }^{66}$, które zamiast wydania aktu administracyjnego organy administracji publicznej mogą zawrzeć z każdym, do kogo ten akt administracyjny miałby zostać skierowany. Natomiast na gruncie prawa polskiego nie funkcjonuje pojęcie umowy publicznoprawnej, a poglądy literatury polskiej w tym zakresie nie sa jednolite. Wynika to zapewne faktu, że instytucja takiej umowy - inaczej niż w Niemczech - nie została uregulowana $\mathrm{W}$ sposób generalny przez przepisy prawa administracyjnego ${ }^{67}$. Natomiast

${ }^{63}$ Por. W. Piątek, Wybrane zagadnienia wykonania wyroku sqdu administracyjnego, w: B. Guzik, N. Buchowska, P. Wiliński (red.), Prawo wobec wyzwań wspótczesności, t. 4, Poznań 2010, s. 318.

${ }^{64}$ H.-D. Lemke, op. cit., s. 44.

${ }^{65}$ Por. M. Szubiakowski, w: M. Wierzbowski, M. Szubiakowski, A. Wiktorowska, Postepowanie administracyjne - ogólne, podatkowe, egzekucyjne i przed sadami administracyjnymi, Warszawa 2006; M. Romańska, Skuteczność orzeczeń sąów administracyjnych, Warszawa 2010, s. 450 i n.

${ }^{66}$ Ustawa o postępowaniu administracyjnym związku stanowi w wymienionym przepisie, że stosunek prawny w obszarze prawa publicznego może zostać ustanowiony, zmieniony albo zniesiony w drodze umowy (umowa publicznoprawna); por. też: H.-D. Lemke, op. cit., s. 45; G. Sadler, Verwaltungs-Vollstreckungsgesetz. Kommentar anhand der Rechtsprechung, Heidelberg 2010, s. 86-87, nb. 56 i n. Przykładów umów publicznoprawnych dostarcza orzecznictwo niemieckich sądów administarcyjnych, które wskazuje na takie przypadki, jak: umowa o budowę obiektu chroniącego przed hałasem na obszarze gminy, umowa według programu ochrony natury Bawarii w celu podtrzymania biocenozy roślin i zwierząt, umowa o przygotowanie infrastruktury gmin w myśl § 124 Kodeksu budowlanego (budowa dróg i urządzeń odwadniających), urbanistyczna umowa wymiany - w rozumieniu §56 VwVfG, umowa zarządzania pomiędzy Republiką Bawarii a obywatelem dotycząca realizacji programu na podstawie art. 14 bawarskiej ustawy o ochronie natury; zob. K. Weber, op. cit., s. 76-77.

${ }^{67}$ Por. Z. Leoński, Zarys prawa administracyjnego, Warszawa 2006, s. 304-305. W literaturze polskiej wskazuje się, że brak wyraźnej regulacji instytucji umowy administracyjnej nie przekreśla wcale możliwości stosowania tej formy przez organy administracji publicznej w danym porządku prawnym zob. Z. Cieślik, Umowa administracyjna $w$ państwie prawa, Kraków 2004, s. 112. Natomiast wielu autorów dostrzega od dawna potrzebę rozważenia wprowadzenia umowy publicznoprawnej do polskiego porządku prawnego - por. J. S. Langrod, Instytucje prawa administracyjnego. Zarys części ogólnej, t. 1, Kraków 1948, s. 280; J. Starościak, Prawne formy $i$ metody dziatania administracji, w: T. Rabska, J. Łętowski, System prawa administracyjnego, t. 3, Wrocław-Warszawa-Kraków-Gdańsk 1978, s. 207; D. Kijowski, W sprawie charakteru prawnego umów zawieranych przez organy administracji, „,Państwo 
polski Kodeks postępowania administracyjnego przewiduje instytucję ugody (art. 114 k.p.a.). Zatwierdzona ugoda wywiera takie same skutki jak decyzja $\mathrm{w}$ toku postępowania administracyjnego (art. 121 k.p.a.). W związku z tym należy przyjaćc, iż - wbrew twierdzeniom niektórych autorów co do niemożności stosowania w tym przypadku przymusu ${ }^{68}$ - zatwierdzona ugoda jest podstawa wszczęcia i prowadzenia egzekucji administracyjnej ${ }^{69}$, pod warunkiem że jej przedmiotem były wykonalne obowiązki działania, znoszenia lub zaniechania.

\section{Publicznoprawne obciążenie nieruchomości (Baulast)}

Niemieckie prawo budowlane przewiduje instytucję publicznoprawnego obciążenia nieruchomości, które powstaje poprzez wspomniany wpis do rejestru takich obciążeń, prowadzonego przez organ nadzoru budowlanego ( 83 ust. 1 zd. I i ust. 2 BauO NRW). Poprzez publiczne obciążenie nieruchomości właściciel tej nieruchomości przyjmuje względem organu nadzoru budowlanego obowiązki publicznoprawne działania, znoszenia lub zaniechania dotyczące działki gruntu, które jednak nie wynikaja z przepisów publicznoprawnych ${ }^{70}$. Klasycznym przykładem występującym $\mathrm{w}$ praktyce, a jednocześnie jednym z najważniejszych w stosowaniu omawianej instytucji, sa tak zwane powierzchnie odstępu ${ }^{71}$. Inny przykład publicznoprawnego obciążenia nieruchomości dostarcza przypadek zaistniały na gruncie $\S 30$ ust. 1 Kodeksu budowlanego z 23 czerwca 1960 r. $^{72}$

W doktrynie prawa niemieckiego stwierdza się, że publiczne obciążenie nieruchomości nie stanowi aktu administracyjnego ${ }^{73}$, gdyż w tej sytuacji organ nie reguluje samodzielnie, $\mathrm{z}$ własnej inicjatywy, konkretnego przypadku. Raczej dokumentuje - na wniosek ,,z zewnątrz" - dobrowolną ugodę stron. W tej perspektywie stwierdza się, że publiczne obciążenie nieruchomości można postawić na równi $\mathrm{z}$ umowa publicznoprawna - jako podstawę egzekucji administracyjnej w rozumieniu $\S 6$ ust. $1 \mathrm{VwVG}^{74}$.

\footnotetext{
i Prawo” 1987, z. 6, s. 87; B. Dolnicki, Umowa publicznoprawna w prawie niemieckim, „Państwo i Prawo” 2001, z. 3, s. 80; J. Wyporska-Frankiewicz, Publicznoprawne formy dziatania administracji o charakterze dwustronnym, Warszawa 2010, s. 237 i n.

68 Tak: P. Ruczkowski, Ugoda administracyjna (procesowa) $w$ prawie polskim $i$ niemieckim, „Przegląd Prawa Publicznego” 2011, nr 9, s. 9.

${ }^{69}$ B. Adamiak, w: eadem, J. Borkowski, Kodeks postepowania administracyjnego. Komentarz, Warszawa 2010, s. 550; R. Hauser, A. Skoczylas, w: K. Celińska-Grzegorczyk, R. Hauser, W. Sawczyn, A. Skoczylas, op. cit., s. 95.

${ }^{70}$ S. Muckel, Öffentliches Baurecht, München 2010, s. 140, nb. 66. Szerzej na temat tej instytucji prawnej m.in.: W. Brohm, Öffentliches Baurecht. Bauplanungs-, Bauordnungs- und Raumordnungsrecht, München 2008, § 4, nb. 16 i n.; F. Stollmann, Öffentliches Baurecht, München 2010, § 18, nb. 33 i n.; F. Rixner, R. Biedermann, S. Steger, Systematischer Praxiskommentar. Baugesetzbuch, Verordnung über die bauliche Nutzung der Grundstücke, Köln 2010, s. 487; H. Jäde, F. Dirnberger, J. Weiß, Baugesetzbuch. Baunutzungsverordnung. Kommentar, Stuttgart-München-Hannover-Berlin-Weimar-Dresden 2010, s. 593.

${ }^{71}$ Niem.: „Abstandflächen”; zob. np. § 6 Prawa budowlanego Kraju Nadrenii Północnej-Wesfalii (Bauordnung für das Land Nordrhein-Westfalen).

${ }^{72}$ Baugesetzbuch, BGBl. I, 2004, s. 2414. Zobacz szerzej na temat tych przykładów: S. Muckel, op. cit., s. 141 , nb. 67 i n.

${ }^{73}$ Odmienny pogląd: OVG Saarlouis (Wyższy Sąd Administracyjny w Saarlouis), wyrok z 18 czerwca 2002 r., 2 R 2/01, NJW 2003, s. 768.

${ }^{74}$ G. Sadler, Verwaltungs-Vollstreckungsgesetz..., s. 87, nb. 60.
} 


\section{PODSUMOWANIE}

Prawo niemieckie i polskie zawiera w zakresie egzekucji administracyjnej obowiązków niepieniężnych tożsame pod względem modelu prawnego rozwiązania odnośnie do kształtu podstawy prawnej egzekucji administracyjnej. Wynika to z przyjęcia w porządkach prawnych obu państw tak zwanej zasady powszechnego przymusu administracyjnego, która oznacza przyznanie organom administracji publicznej upoważnienia do samodzielnego egzekwowania nakładanych przez nią obowiązków publicznoprawnych.

W konsekwencji istnienie indywidualnego aktu administracyjnego konkretyzującego niepieniężny obowiązek działania, znoszenia lub zaniechania $\mathrm{w}$ obu systemach prawnych jest co do zasady jedną z przesłanek egzekucji wskazanych obowiązków administracyjnoprawnych, stanowiąc podstawę wszczęcia i prowadzenia egzekucji. Tym samym na gruncie prawa polskiego błędne jest wskazywanie na administracyjny tytuł wykonawczy - czyli dokument urzędowy stwierdzający dopuszczalność przymusowego wykonania w określonych granicach - jako na podstawę egzekucji administracyjnej ${ }^{75}$.

Akt administracyjny stanowiący podstawę egzekucji musi posiadać ,,zdolność egzekucyjną", którą akt o powyższej treści osiagga przez uzyskanie cechy niezaskarżalności bądź przez nadanie mu przymiotu natychmiastowej wykonalności. Wykonanie $\mathrm{w}$ trybie postępowania przymusowego $\mathrm{w}$ administracji, zarówno w prawie niemieckim, jak i polskim, nie jest zależne od legalności aktu administracyjnego, a jedynie od jego skuteczności.

Znamiennym na gruncie prawa polskiego jest fakt, iż polska ustawa egzekucyjna dopuszcza możliwość przeprowadzenia egzekucji co do obowiązku opartego na przepisie prawa - bez konkretyzowania go w akcie administracyjnym, to znaczy jeśli obowiązek działania, znoszenia lub zaniechania wynika wprost z przepisu. Prawo niemieckie nie dopuszcza takiej możliwości w zakresie tego rodzaju świadczeń. Istotną cechą modelową niemieckiego systemu egzekucji administracyjnej jest także odpowiednie stosowanie przepisów o egzekucji administracyjnej do tytułów sądowoadministracyjnych ( 168 ust. 1 VwGO), a także do umów publicznoprawnych ( $\$ 54$ i nast. VwVfG) oraz tak zwanych publicznych obciążeń nieruchomości - której to instytucji nie zna polskie prawo budowlane.

mgr Przemystaw Ostojski

Wojewódzki Sad Administracyjny w Poznaniu

p.ostojski@wsa.poznan.pl

75 Tak np.: W. Grześkiewicz, Tytut wykonawczy $w$ postępowaniu egzekucyjnym $w$ administracji, „Finanse Komunalne” 2004, nr 10, s. 5. 


\section{THE BASIS FOR ADMINISTRATIVE ENFORCEMENT \\ OF NON-PECUNIARY OBLIGATIONS IN GERMAN AND POLISH LAW}

\section{Summary}

The paper aims to present the basis for administrative enforcement of non-pecuniary obligations an issue not yet discussed in the legal doctrine, or the judgments of administrative courts. The main assumption of the work was that any administrative execution must be sourced in an individual administrative act, which is the basic and most important form of action of public administration. Orders and bans implemented by way of an administrative act and not voluntarily performed become subject of administrative enforcement.

A wider analysis of the discussed issue shows a high degree of similarity in the approach to this legal institution in the German and Polish legal systems. The noted differences concern specific solutions of the general administrative proceedings and certain specific legal institutions present in both systems. 
